\title{
Review \\ The Evolution of Fabrication Methods in Human Retina Regeneration
}

\author{
Beatrice Belgio $^{1, *(1)}$, Anna Paola Salvetti ${ }^{2,3}\left[\right.$, Sara Mantero ${ }^{1}(\mathbb{D})$ and Federica Boschetti ${ }^{1}(\mathbb{C}$ \\ 1 Department of Chemistry, Materials and Chemical Engineering "Giulio Natta”, Politecnico di Milano, \\ 20133 Milan, Italy; sara.mantero@polimi.it (S.M.); federica.boschetti@polimi.it (F.B.) \\ 2 Department of Biomedical and Clinical Science Luigi Sacco, Fatebenefratelli and Sacco Hospital, \\ University of Milan, 20157 Milan, Italy; paola.anna.salvetti@gmail.com \\ 3 Ophthalmology Department, Casa di Cura Beato Palazzolo, 24122 Bergamo, Italy \\ * Correspondence: beatrice.belgio@polimi.it
}

Citation: Belgio, B.; Salvetti, A.P.; Mantero, S.; Boschetti, F. The Evolution of Fabrication Methods in Human Retina Regeneration. Appl. Sci. 2021, 11, 4102. https://doi.org/ 10.3390/app11094102

Academic Editor: Rossella Bedin

Received: 28 February 2021

Accepted: 27 April 2021

Published: 30 April 2021

Publisher's Note: MDPI stays neutral with regard to jurisdictional claims in published maps and institutional affiliations.

Copyright: (c) 2021 by the authors. Licensee MDPI, Basel, Switzerland. This article is an open access article distributed under the terms and conditions of the Creative Commons Attribution (CC BY) license (https:/ / creativecommons.org/licenses/by/ $4.0 /)$.

\begin{abstract}
Optic nerve and retinal diseases such as age-related macular degeneration and inherited retinal dystrophies (IRDs) often cause permanent sight loss. Currently, a limited number of retinal diseases can be treated. Hence, new strategies are needed. Regenerative medicine and especially tissue engineering have recently emerged as promising alternatives to repair retinal degeneration and recover vision. Here, we provide an overview of retinal anatomy and diseases and a comprehensive review of retinal regeneration approaches. In the first part of the review, we present scaffold-free approaches such as gene therapy and cell sheet technology while in the second part, we focus on fabrication techniques to produce a retinal scaffold with a particular emphasis on recent trends and advances in fabrication techniques. To this end, the use of electrospinning, 3D bioprinting and lithography in retinal regeneration was explored.
\end{abstract}

Keywords: retina; tissue engineering; retina regeneration; biofabrication; 3D bioprinting; electrospinning; ophthalmology

\section{Background}

The retina, lining the inner surface of the eye's posterior segment, is a thin light-sensing tissue responsible for light absorption, conversion to an electrical signal and transmission to the brain through the optic nerve. The retina comprises multiple layers of different cells as shown in Figure 1 [1]. Photoreceptors are specialized neurons that convert visual stimuli into electrical impulses. The signal is then processed and transmitted from photoreceptors to the brain by neural cells including retinal ganglion cells (RGCs). The photoreceptors collaborate closely with the underlying retinal pigment epithelium (RPE), which is essential for visual function [2-4]. Hence, the dysfunction or degeneration of RPE cells results in the death of photoreceptors and vision loss [5]. The RPE cell basal surface faces Bruch's membrane, a thin $(2-4 \mu \mathrm{m})$ acellular matrix located between the retina and the choroid. This membrane presents a nanofibrous structure composed of collagen I-V, laminin and fibronectin [6]. Bruch's membrane serves as a physical support for RPE cells and as a barrier regulating the diffusion of biomolecules, nutrients, oxygen, fluids and waste between the retina and the choroidal blood supply $[7,8]$.

Pathologies of the retina and optic nerve represent a leading cause of visual impairment and irreversible blindness in high-income countries [9]. These diseases are usually divided into those caused by mutation in only one gene (monogenic diseases) such as inherited retinal diseases (IRDs) and those caused by mutations in multiple genes and environmental factors (polygenic and/or multifactorial diseases) such as age-related macular degeneration (AMD) and glaucoma [10-14]. As the retina is composed of neuronal highly specialized cells with a limited healing potential, regenerative strategies are necessary to reverse vision loss caused by these diseases. 


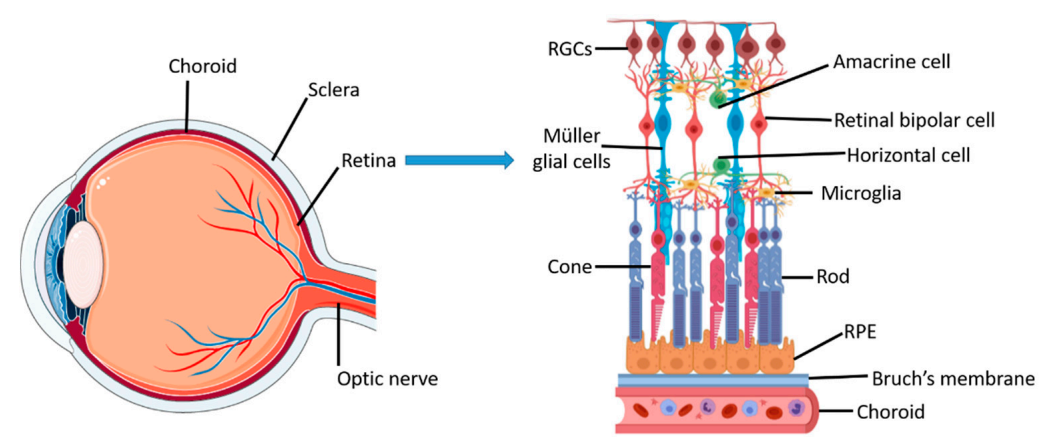

Figure 1. Representation of a cross-section of a human eye and a detail of the multilayer organization of the retina, Bruch's membrane and choroid. The retinal layers include a retinal pigment epithelium (RPE), cone and rod photoreceptors, horizontal cells, bipolar cells, amacrine cells, microglia and Müller glial cells and ganglion cells (RGCs).

This review aims to provide a current account of the developments in retinal regeneration. Retinal regeneration includes tissue engineering approaches and gene- and cell-based therapies, which we refer to as scaffold-free approaches and that are briefly presented in Section 2. Tissue engineering strategies combining cells, a scaffold and chemical cues offer several solutions that are described in Section 3. In particular, we will focus on the regeneration techniques of RGCs, RPE cells along with Bruch's membrane and photoreceptors as these are the cells mainly involved in the majority of pathologies inducing blindness.

\section{Scaffold-Free Approaches}

Gene therapy has been proven to restore vision by replacing absent or abnormal genes causing monogenic retinal diseases [15-17]. Viral vectors and non-viral gene nanocarriers have been used to deliver specific genes to target cells [15]. For instance, for RPE65associated IRDs, nowadays there is an FDA (Food and Drug Administration) and EMA (European Medicine Agency)-approved gene therapy (Luxturna (voretigene neparvovecrzyl), Spark Therapeutics) based on the delivery of a functional copy of the RPE65 gene into RPE cells [17]. Therapies targeting monogenic retinal dystrophies are the most promising. Gene augmentation therapy, however, has its own limitations. Only the recessive forms where the mutations cause a loss of function, also called haploinsufficiency, such that the resulting protein is too little or absent can be currently treated with gene therapy [18].

Another scaffold-free strategy explored to regenerate damaged cells or replace dead cells is cell therapy. Healthy cells can be injected as cell suspension or transplanted as sheets to replace pathological cells, thus preventing further degeneration and improving visual function. For instance, as a possible treatment for glaucoma, the transplantation of RGCs derived from human pluripotent stem cells and from human Müller glia cells was investigated. However, difficulties remain in integrating the transplanted RGCs into the complex neurological network of the host retina [19]. Cell transplantation in animal models has been experimented also to treat AMD. Capela et al. reported that a subretinal injection of human central nervous system stem cells in pigmented dystrophic rats enhanced the proliferation of the host RPE cells, providing a new mechanism for RPE regeneration and thus preserving the viability of photoreceptors [20]. Lu et al. demonstrated that the embryonic stem cell-derived RPE implanted in a pathological mouse model was able to restore visual function in the short term. After 90 days, the visual acuity started decreasing [21]. This reduced efficacy could be due to the lack of interaction between the transplanted cells and Bruch's membrane, thereby not forming a functional monolayer. Phase I/II clinical trials were carried out to determine the primary endpoints of safety and tolerability of a subretinal injection of a cell suspension [22]. No serious adverse effect was encountered; however, concerns about integration efficiency and long term cell survival were raised. A possible approach to overcome this issue is represented by cell sheet engineering $[23,24]$. Cell sheet engineering is based on harvesting a sheet of cells along with their extracellular matrix (ECM) without the use of enzymes [25]. Harvesting 
cells is performed with thermoresponsive coatings that enable reversible cell detachment by switching their surface hydrophobicity. Such an approach may allow the formation of an intact RPE cell monolayer to be transplanted. Furthermore, the presence of an ECM should improve the attachment to the host tissue once implanted [26]. However, the use of cell sheet engineering for the RPE is limited by the insufficient amount of the ECM secreted by these cells [18]. In addition, when multiple structures are involved in the pathology, as in AMD, cell therapy cannot be effective in the long term. For example, Bruch's membrane is also compromised in AMD; therefore, it needs to be replaced along with the RPE monolayer. Alternative strategies are needed to fabricate a mechanically strong tissue that promotes cell attachment and survival while maintaining cell functionality in the long term.

\section{Tissue Engineering Approach}

Tissue engineering has been commonly employed in biomedical applications [27-30]. This approach relies on the use of scaffolds as support systems for adherent cells. Scaffolds should provide a proper in vivo-like microenvironment for tissue regeneration.

Autologous Bruch's membrane explants or its constituent layers were first used as a scaffold for RPE cells to regenerate the outer retina in patients with AMD. According to early studies, the degree of structural support for cell attachment decreases with a decreasing concentration of proteins contained in the RPE basal lamina such as specific laminins [31-35]. To improve the RPE attachment, Bruch's membrane explants were coated with fibronectin, laminin and vitronectin [36-38]. The cell attachment was also enhanced by seeding the RPE cells onto Bruch's membrane explants coated with an ECM previously secreted by corneal endothelial cells [39]. However, the inter-donor variability and limited availability of a native Bruch's membrane have urged researchers to use artificial scaffolds for clinical applications.

The fabrication of artificial scaffolds offers a valid alternative to native tissues. A variety of three-dimensional (3D) scaffolds have been designed and developed for the skin, the bladder, cartilage, bones and muscles [40-44]. Selecting a scaffold fabrication technique and chemical composition is crucial to reproducing the microarchitecture of a native ECM. Here, we provide an overview of the fabrication methods used to engineer a human retina (Figure 2). First, we present the conventional and common methods for retinal scaffold production. We then lay emphasis on the most recent and promising advances in fabrication techniques used for retina tissue engineering.

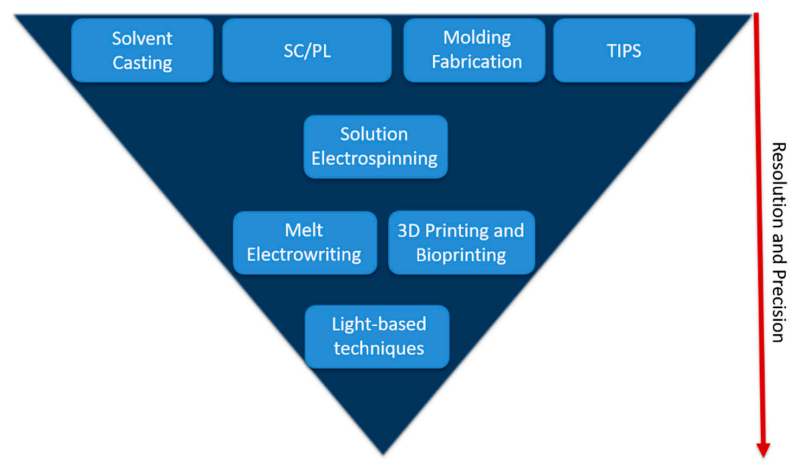

Figure 2. Overview of fabrication methods used for retinal tissue engineering. SC/PL stands for solvent casting-particulate leaching and TIPS for thermally induced phase separation. The red arrow indicates the increase in precision and resolution of the techniques.

\subsection{Conventional Fabrication Techniques}

Solvent casting techniques have been highly utilized in ocular tissue engineering [45]. They consist of dissolving a polymer in an appropriate solvent followed by casting and solvent evaporation [46]. The resulting scaffold is a uniform and non-porous film. In retinal tissue engineering, these films were seeded with RPE cells to regenerate the RPE layer and replace Bruch's membrane for AMD treatment, thus preventing the loss of photorecep- 
tors [47-51]. The prosthetic Bruch's membrane manufactured by solvent casting displayed a similar thickness to the human Bruch's membrane and promoted correct implantation and orientation of the cellular graft in the subretinal space. Moreover, as the degradation of the polymer proceeds, transplanted RPE cells should re-establish interactions with the native Bruch's membrane [47]. To enhance the survival of a functional RPE monolayer in the long term, the film surface was modified [52,53]. Singh et al. showed that silk fibroin scaffolds coated with type I collagen promoted the in vitro development and survival of a functional RPE monolayer for 90 days [52]. Hasirci et al. used oxygen plasma treatment to render a film surface hydrophilic, thus enhancing cell attachment and spreading [53]. However, the film's non-porous structure did not match the open fibrillar structure of the native Bruch's membrane and could prevent nutrient diffusion from the choroid in vivo. To generate a porous scaffold, a solvent casting/particle leaching (SC/PL) method was adopted in biomedical applications [54]. In the SC/PL technique, the solvent, where the polymer is dissolved, contains leachable particles known as porogen [55]. This method allows the production of scaffolds with high porosity (up to 93\%) in a simple, inexpensive way [54]. Prosthetic Bruch's membranes for RPE transplantation were successfully prepared using the SC/PL method [56-58]. Moreover, to develop an optimized cell therapy strategy, the influence of the scaffold pore size on the cell differentiation into the retinal precursor has been investigated [59]. However, the low reproducibility limits the use of the SC/PL technique for retinal tissue engineering applications [60].

Over the last decade, hydrogels have received considerable attention as leading candidates for engineering soft tissues such as the retina due to their unique compositional and structural similarities to the ECM [61]. As such, they are highly hydrophilic and biocompatible, thus promoting cell attachment, proliferation and differentiation. Various methods have been used to produce hydrogels depending on the desired structure and application [61]. The most common method of hydrogel preparation involves the crosslinking of the polymer solution poured into a mold of a specific shape. Crosslinking may occur by physical or chemical methods; the type and degree of crosslinking strongly affects the properties of hydrogels such as the elastic modulus, nutrient transport and swelling capacity [62]. In retina tissue engineering, hydrogels have been employed as scaffolds for RPE, photoreceptors and the regeneration of RGCs [63-70]. For instance, implantable hydrogels with encapsulated cells were proposed as promising candidates to treat those blinding diseases caused by the degeneration of the RPE. Hydrogels acted as a cell delivery vehicle providing an appropriate environment for RPE regeneration [63-65]. Marmorstein et al. seeded an induced pluripotent stem cell (iPSC)-derived RPE onto the surface of thin fibrin hydrogels as a support material for RPE transplantation [66]. The findings of this study indicated that fibrin hydrogels could be easily manipulated with surgical tools and degraded rapidly into products recognized and metabolized by the body. IPSC-RPE cells on a fibrin hydrogel were viable and organized into a functional monolayer that could be preserved during and after implantation thanks to the hydrogel support [66]. However, despite their high biocompatibility, hydrogels have low mechanical properties and, hence, they are not suitable as a Bruch's membrane substitute. In fact, hydrogel stiffness ranges from a few Pa to few $\mathrm{kPa}$ whereas the elastic modulus of Bruch's membrane is estimated to be around few MPa [5]. Hydrogels were also employed as 3D scaffolds for neural retina tissue engineering to regenerate damaged photoreceptors and RGCs [69,70]. Conjunctiva stem cells encapsulated in fibrin gels differentiated into photoreceptor-like cells, thus providing a new potential therapy for diseases involving photoreceptor injuries [70]. Similarly, retinal ganglion-like cells were differentiated from dental pulp stem cells suspended in fibrin gels [69]. This construct could be transplanted into patients with glaucoma to repair axonal damage and prevent further RGC death. The 3D networks resembled the physiological 3D microenvironment of the neural retina, thus promoting cell viability, differentiation and function when compared with 2D cultures [68-70]. However, the molding fabrication method has a limited microarchitecture and cell distribution controllability. 
Another technique that has been explored in retinal tissue engineering is thermally induced phase separation (TIPS). TIPS induces the destabilization of a homogenous solution composed of a polymer dissolved in a solvent [71]. After dissolution, a polymer can be thermodynamically unstable at low temperatures, thus causing a spontaneous separation of the solution into a polymer-rich phase and a solvent-rich phase. Lowering the temperature in a controlled manner causes the solidification of the solvent and subsequently the separation of the polymer from the solvent. The solvent crystals are then removed through extraction, evaporation and sublimation resulting in porous structures [72]. The TIPS method has been largely employed for tissue engineering applications in general, for example, bones and cartilage, due to its ability to produce highly porous scaffolds with interconnected pores [73-75]. Porous membranes, fabricated by a separation phase, were investigated as a scaffold for RPE transplantation [76]. TIPS was also used to fabricate scaffolds for retinal progenitor cells isolated from mice eyes [77]. Seeded scaffolds were tested in vitro and then implanted into models of retinal degeneration. The outcomes of this study indicated that the scaffolds promoted cell differentiation in vitro and cell survival in vivo [77]. The guidance of cell differentiation by the substrate could be exploited to form functional photoreceptors to replace the cells lost due to degenerative diseases. However, the use of the TIPS technique is limited by the low control of pore size and geometry [73].

The retinal scaffolds produced by conventional techniques are listed in Table 1. Due to their own limits, the conventional fabrication methods have been mostly replaced by innovative techniques that hold great promise as potential treatments for retinal degenerative diseases.

Table 1. A summary of scaffolds produced by conventional methods and used for retinal tissue engineering. This table highlights the fabrication technique, the structure of the scaffold and the cell type used. SC/PL: solvent casting-particle leaching; TIPS: thermally induced phase separation; RPE: retinal pigment epithelium; ESC: embryonic stem cells; iPSC: induced pluripotent stem cells; RGC: retinal ganglion cells.

\begin{tabular}{|c|c|c|c|c|}
\hline Fabrication Technique & Scaffold Structure & Cell Type & Research Stage & Reference \\
\hline Solvent casting & Non-porous film & Human fetal RPE cells & In vitro & [47] \\
\hline Solvent casting & Non-porous film & Human cell line ARPE-19 & $\begin{array}{l}\text { In vitro and in vivo } \\
\text { (rabbit) }\end{array}$ & [48] \\
\hline Solvent casting & Non-porous film & Human cell line ARPE-19 & $\begin{array}{l}\text { In vitro and in vivo } \\
\text { (rabbit) }\end{array}$ & [49] \\
\hline Solvent casting & Non-porous film & Human cell line ARPE-19 & In vitro & {$[50]$} \\
\hline Solvent casting & Non-porous film & Human RPE cells & In vitro & [51] \\
\hline Solvent casting & Non-porous film & Human iPSC-RPE cells & In vitro & [52] \\
\hline Solvent casting & Non-porous film & Human cell line D407 & In vitro & [53] \\
\hline $\mathrm{SC} / \mathrm{PL}$ & Porous membrane & Human cell line ARPE-19 & In vitro & [56] \\
\hline $\mathrm{SC} / \mathrm{PL}$ & Porous membrane & Human fetal RPE cells & In vitro & [57] \\
\hline $\mathrm{SC} / \mathrm{PL}$ & Porous membrane & Human ESC-RPE cells & In vitro & [58] \\
\hline $\mathrm{SC} / \mathrm{PL}$ & Porous membrane & Human or pig RPE & In vitro & [59] \\
\hline Silicon Mold & $\begin{array}{l}\text { 3D hydrogel with } \\
\text { cells encapsulated }\end{array}$ & Rabbit RPE cells & In vitro & [63] \\
\hline Petri dish Mold & $\begin{array}{l}\text { 3D hydrogel with } \\
\text { cells encapsulated }\end{array}$ & Human cell line ARPE-19 & In vitro & [64] \\
\hline Mold & $\begin{array}{l}\text { 3D hydrogel with } \\
\text { cells encapsulated }\end{array}$ & $\begin{array}{l}\text { Human iPSC- and } \\
\text { ESC-derived embryoid } \\
\text { bodies }\end{array}$ & In vitro & [65] \\
\hline $\begin{array}{l}\text { Custom or well plates } \\
\text { mold }\end{array}$ & Thin hydrogel & Human iPSC-RPE cells & In vitro & [66] \\
\hline Custom mold & Thin gel film & Human cell line ARPE-19 & In vitro & [67] \\
\hline Mold & 3D hydrogel & Rat RGCs and amacrine cells & In vitro & [68] \\
\hline Well plate mold & $\begin{array}{l}\text { 3D hydrogel with } \\
\text { cells encapsulated }\end{array}$ & Rat dental pulp stem cells & In vitro & [69] \\
\hline Well plate mold & $\begin{array}{l}\text { 3D hydrogel with } \\
\text { cells encapsulated }\end{array}$ & $\begin{array}{l}\text { Human conjunctiva } \\
\text { mesenchymal stem cells }\end{array}$ & In vitro & [70] \\
\hline TIPS & Porous membrane & Human cell line ARPE-19 & In vitro & [76] \\
\hline TIPS & Porous membrane & Rat retinal progenitor cells & In vitro and in vivo (rats) & [77] \\
\hline
\end{tabular}




\subsection{Electrospinning}

The electrospinning process has been suggested as a promising technique to fabricate a prosthetic Bruch's membrane as it is able to recapitulate the nanofibrous structure of a native Bruch's membrane [78]. Indeed, the electrospinning technique is able to produce 3D thin nanofibrous membranes by using natural and synthetic polymers [79]. These fibrillar networks are highly permeable for solutes, thus facilitating cell adhesion and proliferation [79]. The electrospinning setup involves a high-voltage supply, a capillary tube/syringe with a needle, a syringe pump and a collector. The high-voltage supply applies a positive charge to a polymeric solution (solution electrospinning) or melt (melt electrospinning) that is extruded from the needle forming a jet. The jet becomes unstable and thin and forms fibers while the solvent evaporates. The fibers are deposited onto a collector [80]. The morphological properties of electrospun membranes such as thickness, fiber size and orientation can be tuned simply by changing the specific parameters of the electrospinning process such as the polymer concentration, solution flow rate and collector distance [81]. Many studies have reported the fabrication of electrospun scaffolds for vascular, cardiac and neural tissue engineering [82-84].

Solution electrospinning has been utilized to produce a prosthetic Bruch's membrane to engineer an RPE layer. The hypothesis is that the RPE monolayer engineered on thin electrospun membranes could become an effective therapy to cure blindness and the deficiencies associated with RPE and Bruch's membrane degeneration. Synthetic and natural polymers including poly(lactic acid) (PLA), poly( $\varepsilon$-caprolactone) (PCL) and poly(lacticco-glycolic acid) (PLGA), silk fibroin and silk fibroin-PCL-gelatin were used to fabricate electrospun Bruch's membrane-like scaffolds [85-100]. Typically, a blend of natural and synthetic materials is electrospun as synthetic polymers exhibit good mechanical properties and a controlled degradation rate while pure naturally-derived polymers promote cell adhesion and proliferation. Warnke et al. successfully produced ultrathin nanofibrous scaffolds based on collagen and PLGA that closely imitated the structure of a native Bruch's membrane [85]. Human RPE cells seeded onto these scaffolds formed a functional monolayer with a typical cobblestone morphology and abundant sheet-like microvilli on their apical surfaces; however, no results of the scaffold mechanics and permeability were reported [85]. In our previous paper, we fabricated a Bruch's membrane-like membrane composed of a blend of Bombyx mori silk fibroin and PCL to study the pathological mechanisms of AMD in a 3D in vitro model [100]. The resulting scaffolds showed similarities with a human Bruch's membrane with regard to the architecture, permeability and mechanical properties [100]. These in vitro studies indicated the feasibility of using electrospun membranes as a prosthetic Bruch's membrane on which a functional RPE monolayer is formed. As such, RPE patches, composed of electrospun scaffolds previously seeded with RPE cells, have been investigated in vivo. The RPE patches were proven to be biocompatible when implanted in animal models showing no adverse reactions $[86,89,92,95,98]$. Sharma et al. also evaluated the functionality of clinical-grade iPSC-RPE patches in rats and in a porcine laser-injured model. According to the findings, the use of the scaffold improved the patch integration and efficacy over the cell suspension [95]. In fact, an increased photoreceptor preservation was encountered in animals transplanted with the patch in respect to those injected with the cell suspension. This study has led to a phase I/II clinical trial (NCT04339764) based on patch subretinal transplantation in patients suffering from advanced stages of dry AMD.

Electrospun scaffolds have been employed also in neural retina engineering to guide the growth of RGC axons through the control of fiber orientation [101-103]. This approach could benefit patients suffering from glaucoma and optic nerve diseases. The transplantation of functional RGCs onto a suitable support combined with treatments that promote dendritic integration may regenerate axons and help recreate a healthy axonal transport. Radially oriented scaffolds have been investigated for the transplantation of RGCs as they mimic the radial axon pattern [101]. It was observed that radially oriented scaffolds increased the survival of RGCs while preserving the cellular electrophysiological function. Moreover, these scaffolds promoted RGC axonal integration with the host retinal nerve fibers in retinal rat explants whereas RGCs transplanted directly onto explants grew axons in a random 
pattern [101]. Soleimani et al. compared radially and randomly oriented scaffolds to regenerate photoreceptors. They found that the expression of rod photoreceptor-specific genes increased when stem cells were differentiated on randomly oriented nanofibers [104]. Electrospun scaffolds for retina applications are summarized in Table 2.

Table 2. A summary of retinal scaffolds fabricated by electrospinning. This table highlights the fabrication technique, the structure of the scaffold and the cell type used. RPE: retinal pigment epithelium; ESC: embryonic stem cells; iPSC: induced pluripotent stem cells; RGC: retinal ganglion cells.

\begin{tabular}{|c|c|c|c|c|}
\hline Fabrication Technique & Scaffold Structure & Cell Type & Research Stage & Reference \\
\hline Electrospinning & $\begin{array}{l}\text { Ultrathin random nanofibrous } \\
\text { membrane }\end{array}$ & Human RPE cells & In vitro & [85] \\
\hline Electrospinning & $\begin{array}{l}\text { Ultrathin random nanofibrous } \\
\text { membrane }\end{array}$ & Human RPE cells & $\begin{array}{l}\text { In vitro and } \\
\text { in vivo (rabbit) }\end{array}$ & [86] \\
\hline Electrospinning & $\begin{array}{c}\text { Random nanofibrous } \\
\text { membrane }\end{array}$ & Rat retinal progenitor cells & In vitro & [87] \\
\hline Electrospinning & $\begin{array}{l}\text { Random nanofibrous } \\
\text { membrane }\end{array}$ & Porcine RPE cells & $\begin{array}{l}\text { In vitro and } \\
\text { ex vivo (pig) }\end{array}$ & [88] \\
\hline Electrospinning & $\begin{array}{l}\text { Random nanofibrous } \\
\text { membrane }\end{array}$ & Human RPE cells & $\begin{array}{l}\text { In vitro and } \\
\text { in vivo (rat) }\end{array}$ & [89] \\
\hline Electrospinning & $\begin{array}{l}\text { Random nanofibrous } \\
\text { membrane }\end{array}$ & $\begin{array}{l}\text { Human fetal and adult } \\
\text { RPE cells }\end{array}$ & In vitro & [90] \\
\hline Electrospinning & $\begin{array}{l}\text { Random nanofibrous } \\
\text { membrane }\end{array}$ & Human RPE cells & In vitro & [91] \\
\hline Electrospinning & $\begin{array}{l}\text { Random nanofibrous } \\
\text { membrane }\end{array}$ & Human fetal RPE cells & $\begin{array}{c}\text { In vitro and } \\
\text { in vivo (rabbit) }\end{array}$ & [92] \\
\hline Electrospinning & $\begin{array}{l}\text { Random nanofibrous } \\
\text { membrane }\end{array}$ & Human RPE cells & In vitro & [93] \\
\hline Electrospinning & $\begin{array}{l}\text { Random nanofibrous } \\
\text { membrane }\end{array}$ & Human ESC-RPE cells & In vitro & [94] \\
\hline Electrospinning & $\begin{array}{l}\text { Random nanofibrous } \\
\text { membrane }\end{array}$ & Human iPSC-RPE cells & $\begin{array}{c}\text { In vitro and } \\
\text { in vivo (rat/porcine) }\end{array}$ & [95] \\
\hline Electrospinning & Nanofibrous membrane & $\begin{array}{c}\text { Human ESC-RPE/bovine } \\
\text { RPE cells }\end{array}$ & In vitro & {$[96]$} \\
\hline Electrospinning & $\begin{array}{l}\text { Random nanofibrous } \\
\text { membrane }\end{array}$ & Human RPE cells & In vitro & [97] \\
\hline Electrospinning & $\begin{array}{l}\text { Random nanofibrous } \\
\text { membrane }\end{array}$ & $\begin{array}{l}\text { Human cell line } \\
\text { ARPE-19/MIO-M1 }\end{array}$ & $\begin{array}{l}\text { In vitro and } \\
\text { in vivo (rat) }\end{array}$ & [98] \\
\hline Electrospinning & $\begin{array}{l}\text { Random nanofibrous } \\
\text { membrane }\end{array}$ & Rat retinal progenitor cells & In vitro & [99] \\
\hline Electrospinning & $\begin{array}{l}\text { Random nanofibrous } \\
\text { membrane }\end{array}$ & Human cell line ARPE-19 & In vitro & [100] \\
\hline Electrospinning & $\begin{array}{l}\text { Aligned nanofibrous } \\
\text { membrane }\end{array}$ & Rat RGCs & $\begin{array}{l}\text { In vitro and } \\
\text { ex vivo (rat) }\end{array}$ & [101] \\
\hline Electrospinning & $\begin{array}{l}\text { Aligned nanofibrous } \\
\text { membrane }\end{array}$ & Rat RGCs & In vitro & [102] \\
\hline Electrospinning & $\begin{array}{c}\text { Random nanofibrous } \\
\text { membrane }\end{array}$ & Human iPSC-RGCs & $\begin{array}{c}\text { In vitro and } \\
\text { in vivo } \\
\text { (rabbit/monkey) }\end{array}$ & [103] \\
\hline Electrospinning & $\begin{array}{c}\text { Random }+ \text { aligned nanofibrous } \\
\text { membranes }\end{array}$ & $\begin{array}{l}\text { Human conjunctiva stem } \\
\text { cells }\end{array}$ & In vitro & [104] \\
\hline
\end{tabular}

Despite the advantages, the electrospinning technique has a limited microarchitecture controllability. Therefore, to overcome this drawback, melt electrowriting (MEW) has been recently developed [105]. MEW allows the controlled deposition of a polymer melt fiber starting from a digital model, thus combining melt electrospinning and additive manufacturing principles. To the best of our knowledge, this innovative method has been used in vascular, bone and skin tissue engineering but no studies on a retinal application are yet present [106-108]. 


\subsection{Lithography}

Lithography is a technique that allows the formation of precise and complex $2 \mathrm{D}$ and 3D microarchitectures and nanoarchitectures. In the field of biomedicine, photolithography has offered a promising alternative to a conventional fabrication method [109]. Photolithography is a photon-based technique that exploits light to project a mask into a photosensitive emulsion (photoresist) coated onto a substrate. The master fabricated by photolithography can be used to create a polymer negative mold typically of polydimethylsiloxane (PDMS) for a polymeric scaffold fabrication [109]. Retinal progenitor cells were successfully seeded onto structures fabricated through photolithography [110-112]. The microfabricated topography enhanced the attachment, organization and differentiation of the progenitor cells into photoreceptor-like cells [111]. Hence, these structures could be used for photoreceptor replacement in the treatment of photoreceptor degeneration. Photolithography might be followed by wet and ion etching. For instance, Lu et al. developed and tested in vitro a parylene-C membrane artificial Bruch's membrane for an RPE cell culture as a potential treatment for dry AMD $[8,113]$. In vivo studies demonstrated the safety and potential of a parylene membrane as an RPE scaffold [8]. In particular, the implantation of the membrane previously seeded with cells was compared with the injection of a cell suspension. The results showed that cell survival was greater in animals that were transplanted with the cell membrane patch than those that received the cell suspension. Moreover, when injected, cells were observed as clumps whereas an RPE monolayer was visible in rats transplanted with the patch. These findings suggest that this approach may improve visual function at least in the short term in a few patients suffering from advanced stages of dry AMD. Currently, there is an ongoing clinical trial at phase I/IIa (NCT02590692) to study the safety of subretinal implantation of human embryonic stem cells seeded onto a parylene membrane [114].

The retinal scaffolds fabricated via photolithography are listed in Table 3.

Table 3. A summary of retinal scaffolds fabricated by lithography techniques. This table highlights the fabrication technique, the structure of scaffold and the cell type used. RPE: retinal pigment epithelium; ESC: embryonic stem cells.

\begin{tabular}{ccccc}
\hline Fabrication Technique & Scaffold Structure & Cell Type & Research Stage & Reference \\
\hline Photolithography & Porous scaffold & $\begin{array}{c}\text { Mouse retinal progenitor } \\
\text { cells }\end{array}$ & In vitro & In vitro \\
Photolithography & Thin film scaffold & $\begin{array}{c}\text { Mouse retinal progenitor } \\
\text { cells }\end{array}$ & Mouse retinal progenitor \\
cells & In vitro and in vivo \\
(mouse) & In vitro & [111] \\
$\begin{array}{c}\text { Photolithography } \\
\begin{array}{c}\text { and ion etching } \\
\text { Photolithography + wet } \\
\text { and ion etching }\end{array}\end{array}$ & $\begin{array}{c}\text { Porous scaffold } \\
\text { submicron membrane } \\
\text { submicron membrane }\end{array}$ & ARPE-19/H9-RPE & Human ESC-RPE cells & In vitro and in vivo (rat) \\
\hline
\end{tabular}

\subsection{D Bioprinting}

To overcome the lack of a fine control of structural aspects, additive manufacturing (AM) techniques have been introduced into the tissue engineering area. AM is a process by which a digital model for a 3D object is assembled in a layer-by-layer manner [115]. AM advantages include the ability to fabricate complex geometries with multimaterial parts [115]. Among these techniques, 3D printing plays a key role in developing personalized treatments, surgical planning and the testing deployment of devices in realistic pathways due to its potential to fabricate patient-specific 3D structures in a cost-, time- and waste-effective manner [116]. In the medical field, the latest promising evolution of 3D printing is $3 \mathrm{D}$ bioprinting.

3D bioprinting is an innovative biofabrication strategy, which allows the precise positioning of non-living materials, as in 3D printing, and living materials in a prescribed 3D hierarchical organization [117]. During the bioprinting process, the bioinks, composed of cells 
embedded in biocompatible materials, are dispensed to form the functional desired structures. 3D bioprinting aims to create 3D bioengineered structures serving in regenerative medicine, pharmacokinetics and basic cell biology studies [117]. Such 3D bioprinted constructs can be then cultured in bioreactor systems to obtain mature functional tissues and organs [118]. A few examples of 3D bioprinted scaffolds are represented by synthetic skin to be transplanted onto patients with burn injuries, heart valve replication and bionic ears [119-121]. Currently, there are mainly three types of bioprinting systems (laser-based, inkjet-based and extrusion-based) characterized by a high deposition accuracy, stability and cell viability [117].

Laser-based technology exploits a pulsed laser source and an optical path to focus a laser on a target from which the bioink is printed and deposited onto a substrate. The target is composed of a glass slide, a metal slide and bioink. The laser is focused through the glass slide onto the metal slide inducing a vaporization of the metal-absorbing layer, thus resulting in the production of a jet of bioink. Many researchers have demonstrated that cells were highly viable after laser-based 3D bioprinting [122]. However, cell placement accuracy can be challenging and, in addition, this technology is expensive and relatively slow.

On the contrary, inkjet-based bioprinting is an inexpensive and simple to use technology while offering a relatively high resolution and cell viability [122]. In inkjet bioprinting, small droplets of bioink are ejected from a nozzle through microheater or piezoelectric systems and then dispensed onto a substrate [122]. Inkjet bioprinting was investigated to seed RGCs and glial cells. The technology did not affect the survival and the growth of rat RGCs and glial cells compared with cells seeded onto tissue culture plates [123]. This result opens the way for developing a printed construct to be used in retinal regeneration. Recently, a $3 \mathrm{D}$ in vitro retina model comprising of RPE cells and photoreceptors was fabricated using inkjet-based technology to study the interaction between the layers in AMD disease [124]. According to the authors, after bioprinting both cell types were correctly positioned in a layered structure and expressed specific proteins such as tight junction-associated protein ZO-1 in the RPE layer and light-sensitive proteins in the photoreceptor layer [124]. The use of inkjet-printed structures for tissue engineering is limited by their low mechanical properties and their long term durability. Moreover, due to the presence of the nozzle, clogging issues are common with viscous bioink [122].

The extrusion-based technology relies on the extrusion of continuous filaments of bioink through a nozzle using a driving force, i.e., a piston, a screwing system or pneumatic pressure. It is the most versatile bioprinting process as it enables the printing of the broadest range of bioink viscosities [122]. Additionally, it allows clinically relevant constructs to be obtained in terms of size and shape. However, the rheological requirements of the bioink are stringent [125]. Extrusion-based bioprinting was investigated to produce a 3D in vitro model of the RPE and photoreceptor layers [126]. The RPE cell line was bioprinted with a precise pattern and allowed to form a monolayer in 14 days followed by the bioprinting of the photoreceptor cell line [126]. Such a bioprinted construct could be meaningful for biomedical applications such as disease research and high-throughput screening.

So far, the bioprinted retinal construct has been used only as in vitro models that could be used in the future for basic research and drug screening (Table 4). However, this technology is very promising also for retinal tissue engineering due to the possibility of generating layer-by-layer a 3D complex multicellular stratified structure, which mimics the retina architecture and could be transplanted as potential therapies for retinal diseases involving the degeneration or dysfunction of multiple retinal layers.

Table 4. A summary of 3D bioprinting techniques used in retinal applications. This table highlights the fabrication technique, the structure of the scaffold and the cell type used. RGC: retinal ganglion cells.

\begin{tabular}{ccccc}
\hline Fabrication Technique & Scaffold Structure & Cell Type & Research Stage & Reference \\
\hline Inkjet bioprinting & Not applicable & Rat RGCs and retinal glia & In vitro & [123] \\
Inkjet bioprinting & 3D bilayer retina model & Human cell line ARPE-19 and pig & In vitro & [124] \\
Extrusion bioprinting & 3D bilayer retina model & Human cell line ARPE-19 and Y79 & In vitro & [126] \\
\hline
\end{tabular}




\subsection{Hybrid Approach}

Recently, researchers have focused on combining two or more fabrication approaches for maximal treatment efficacy (Table 5). Tan et al. combined SC/PL and TIPS to develop ultrathin polymer membranes as a prosthetic Bruch's membrane for an RPE replacement [127]. Solvent casting and photolithography were exploited to produce a polyester-based micropatterned film for RPE cells [128]. Shi et al. developed a hybrid approach to fabricate a 3D in vitro model that comprised an artificial Bruch's membrane, a bioprinted ARPE-19 cell monolayer and a Y79 cell-laden alginate/pluronic bioink [129]. This model could be used in the future to study the pathological mechanisms underlying AMD. Another hybrid approach based on electrospinning and 3D bioprinting has been established for the replacement of RGCs as a promising therapy for glaucoma [130]. RGCs were precisely seeded onto an electrospun scaffold via a thermal inkjet 3D cell printing technique. The electrospun scaffold guided the growth of the RGCs [130].

Table 5. A summary of hybrid approaches used in retinal applications. This table highlights the fabrication technique, the structure of the scaffold and the cell type used. RGC: retinal ganglion cells.

\begin{tabular}{ccccc}
\hline Fabrication Technique & Scaffold Structure & Cell Type & Research Stage & Reference \\
\hline SC/PL + TIPS & $\begin{array}{c}\text { Ultrathin, free-standing, } \\
\text { porous membrane }\end{array}$ & Human cell line ARPE-19 & In vitro & [127] \\
SC + photolithography & Micropatterned film & Human cell line D407 & In vitro & [128] \\
SC + 3D bioprinting & $\begin{array}{c}\text { 3D construct: ultrathin } \\
\text { membrane + bilayer model }\end{array}$ & $\begin{array}{c}\text { Human cell line ARPE-19 } \\
\text { and Y79 }\end{array}$ & In vitro & [129] vitro \\
$\begin{array}{c}\text { Electrospinning + 3D } \\
\text { bioprinting }\end{array}$ & $\begin{array}{c}\text { Nanofibrous membrane }+ \\
\text { bioprinted cells }\end{array}$ & Rat RGCs & [130] \\
\hline
\end{tabular}

\section{Conclusions}

Regenerative medicine research and optimization carries enormous hope as means to restore visual function compromised by retinal diseases. In this review, we reported both the conventional and recently developed methods to produce scaffolds for retinal tissue engineering. We believe that innovative tissue engineering techniques open the way for new therapies based on retinal grafts that could be implanted and reverse cell loss. Moreover, new tissue engineering strategies in conjunction with gene therapy holds great promise for the development of innovative clinical treatments to cure retinal diseases.

Funding: This research received no external funding.

Conflicts of Interest: The authors declare no conflict of interest.

\section{References}

1. Hoon, M.; Okawa, H.; Della Santina, L.; Wong, R.O.L. Functional architecture of the retina: Development and disease. Prog. Retin. Eye Res. 2014, 42, 44-84. [CrossRef] [PubMed]

2. Strauss, O. The retinal pigment epithelium in visual function. Prog. Retin. Eye Res. 2005, 85, 845-881. [CrossRef]

3. Adijanto, J.; Banzon, T.; Jalickee, S.; Wang, N.S.; Miller, S.S. $\mathrm{CO}_{2}$-induced ion and fluid transport in human retinal pigment epithelium. J. Gen. Physiol. 2009, 133, 603-622. [CrossRef] [PubMed]

4. Kiser, P.D.; Golczak, M.; Palczewski, K. Chemistry of the Retinoid (Visual) Cycle. Chem. Rev. 2014, 114, 194-232. [CrossRef] [PubMed]

5. Murakami, Y.; Notomi, S.; Hisatomi, T.; Nakazawa, T.; Ishibashi, T.; Miller, J.W.; Vavvas, D.G. Photoreceptor cell death and rescue in retinal detachment and degenerations. Prog. Retin. Eye Res. 2014, 37, 1-55. [CrossRef]

6. Curcio, C.; Johnson, M. Structure, function, and pathology of Bruch's membrane. In Retina, 5th ed.; Elsevier: London, UK, 2013; Volume 1, pp. 466-481.

7. Booji, J.C.; Baas, D.C.; Beisekeeva, J.; Gorgels, T.G.M.F.; Bergen, A.A.B. The dynamic nature of Bruch's membrane. Prog. Retin. Eye Res. 2010, 29, 1-18. [CrossRef]

8. Diniz, B.; Thomas, P.; Thomas, B.; Ribeiro, R.; Hu, Y.; Brant, R.; Ahuja, A.; Zhu, D.; Liu, L.; Koss, M.; et al. Subretinal implantation of retinal pigment epithelial cells derived from human embryonic stem cells: Improved survival when implanted as monolayer. Investig. Ophthalmol. Vis. Sci. 2013, 26, 5087-5096. [CrossRef]

9. Dutt, K.; Cao, Y. Engineering retina from human retinal progenitors (cell lines). Tissue Eng. A 2009, 15, 1401-1413. [CrossRef] 
10. Wong, W.L.; Su, X.; Li, X.; Cheung, C.M.; Klein, R.; Cheng, C.Y.; Wong, T.Y. Global prevalence of age-related macular degeneration and disease burden projection for 2020 and 2040: A systematic review and meta-analysis. Lancet Glob. Health 2014, 2, 106-116. [CrossRef]

11. Bird, A.C. Pathogenic mechanisms in age-related macular degeneration. In Retina, 5th ed.; Elsevier Inc.: London, UK, 2013; Volume 1, pp. 1145-1149.

12. Fernandez-Robredo, P.; Sancho, A.; Johnen, S.; Recalde, S.; Gama, N.; Thumann, G.; Groll, J.; Garcia-Layana, A. Current Treatment Limitations in Age-Related Macular Degeneration and Future Approaches Based on Cell Therapy and Tissue Engineering. Ophthalmology 2014, 1-13. [CrossRef]

13. Jonas, J.B.; Aung, T.; Bourne, R.R.; Bron, A.M.; Ritch, R.; Panda-Jonas, S. Glaucoma. Lancet 2017, 390, 2183-2193. [CrossRef]

14. Weinreb, R.N.; Aung, T.; Medeiros, F.A. The Pathophysiology and Treatment of Glaucoma. JAMA 2015, 311, 1901-1911. [CrossRef] [PubMed]

15. Sahle, F.F.; Kim, S.; Niloy, K.K.; Tahia, F.; Fili, C.V.; Cooper, E.; Hamilton, D.J.; Lowe, T.L. Nanotechnology in Regenerative Ophthalmology. Adv. Drug Deliv. Rev. 2019, 148, 290-307. [CrossRef] [PubMed]

16. Heier, J.S.; Kherani, S.; Desai, S.; Dugel, P.; Kaushal, S.; Cheng, S.H.; Delacono, C.; Purvis, A.; Richards, S.; Le-Halpere, A.; et al. Intravitreous injection of AAV2-sFLT01 in patients with advanced neovascular age-related macular degeneration: A phase 1, open-label trial. Lancet 2017, 390, 50-61. [CrossRef]

17. Georgiou, M.; Fujinami, K.; Michaelides, M. Inherited retinal diseases: Therapeutics, clinical trials and end points-A review. Clin. Exp. Ophthalmol. 2021, 49, 270-288. [CrossRef]

18. Tan, Y.S.E.; Shi, P.J.; Choo, C.J.; Laude, A.; Yeong, W.Y. Tissue engineering of retina and Bruch's membrane: A review of cells, materials and processes. Br. J. Ophthalmol. 2018, 102, 1182-1187. [CrossRef]

19. Fu, L.; Kwok, S.S.; Chan, Y.K.; Lai, J.S.M.; Pan, W.; Nie, L.; Shih, K.C. Therapeutic Strategies for Attenuation of Retinal Ganglion Cell Injury in Optic Neuropathies: Concepts in Translational Research and Therapeutic Implications. Biomed. Res. Int. 2019, 2019, 1-10. [CrossRef]

20. McGill, T.J.; Osborne, L.; Lu, B.; Stoddard, J.; Huhn, S.; Tsukamoto, A.; Capela, A. Subretinal Transplantation of Human Central Nervous System Stem Cells Stimulates Controlled Proliferation of Endogenous Retinal Pigment Epithelium. Transl. Vis. Sci. Technol. 2019, 8, 43-54. [CrossRef]

21. Lu, B.; Malcuit, C.; Wang, S.; Girman, S.; Francis, P.; Lemieux, L.; Lanza, R.; Lund, R. Long-term safety and function of RPE from human embryonic stem cells in preclinical models of macular degeneration. Stem Cells 2009, 27, 2126-2135. [CrossRef] [PubMed]

22. Singh, M.S.; Park, S.S.; Albini, T.A.; Canto-Soler, M.V.; Klassen, H.; MacLaren, R.E.; Takahashi, M.; Nagiel, A.; Schwartz, S.D.; Bharti, K. Retinal stem cell transplantation: Balancing safety and potential. Prog. Retin. Eye Res. 2020, 75, 100779. [CrossRef] [PubMed]

23. Mandai, M.; Watanabe, A.; Kurimoto, Y. Autologous Induced Stem-Cell-Derived Retinal Cells for Macular Degeneration. N. Engl. J. Med. 2017, 376, 1038-1046. [CrossRef] [PubMed]

24. Kubota, A.; Nishida, K.; Yamato, M.; Yang, J.; Kikuchi, A.; Okano, T.; Tano, Y. Transplantable retinal pigment epithelial cell sheets for tissue engineering. Biomaterials 2006, 27, 3639-3644. [CrossRef]

25. Chen, G.; Qi, Y.; Niu, L.; Dl, T.; Zhong, J.; Fang, T.; Yan, W. Application of the cell sheet technique in tissue engineering. Biomed. Rep. 2015, 3, 749-757. [CrossRef]

26. Haraguchi, Y.; Shimizu, T.; Yamato, M.; Okano, T. Scaffold-free tissue engineering using cell sheet technology. RSC Adv. 2012, 2, 2184-2190. [CrossRef]

27. Langer, R.; Vacanti, J. Advances in Tissue Engineering. J. Pediatr. Surg. 2016, 51, 8-12. [CrossRef]

28. Asnaghi, M.A.; Candiani, G.; Farè, S.; Fiore, G.B.; Petrini, P.; Raimondi, M.T.; Soncini, M.; Mantero, S. Trends in biomedical engineering: Focus on Regenerative Medicine. J. Appl. Biomater. Biomech. 2011, 9, 73-86. [CrossRef]

29. Curtis, M.W.; Russel, B. Cardiac Tissue Engineering. J. Cardiovasc. Nurs. 2009, 24, 87-92. [CrossRef]

30. Shafiee, A.; Atala, A. Tissue Engineering: Toward a New Era of Medicine. Annu. Rev. Med. 2017, 14, 29-40. [CrossRef]

31. Del Priore, L.V.; Tezel, T.H. Reattachment rate of human retinal pigment epithelium to layers of human Bruch's membrane. Arch. Ophthalmol. 1998, 116, 335-341. [CrossRef] [PubMed]

32. Tezel, T.H.; Kaplan, H.J.; Del Priore, L.V. Fate of human retinal pigment epithelial cells seeded onto layers of human Bruch's membrane. Investig. Ophthalmol. Vis. Sci. 1999, 40, 467-476.

33. Tezel, T.H.; Del Priore, L.V. Repopulation of different layers of host human Bruch's membrane by retinal pigment epithelial cell grafts. Investig. Ophthalmol. Vis. Sci. 1999, 40, 767-774.

34. Gullapalli, V.K.; Sugino, I.K.; Van Patten, Y.; Shah, S.; Zarbin, M.A. Impaired RPE survival on aged submacular humanBruch's membrane. Exp. Eye Res. 2005, 80, 235-248. [CrossRef]

35. Gullapalli, V.K.; Sugino, I.K.; Van Patten, Y.; Shah, S.; Zarbin, M.A. Retinal pigment epithelium resurfacing of aged submacular human Bruch's membrane. Trans. Am. Ophthalmol. Soc. 2004, 102, 123-137.

36. Tezel, T.H.; Del Priore, L.V.; Kaplan, H.J. Reengineering of aged Bruch's membrane to enhance retinal pigment epithelium repopulation. Investig. Ophthalmol. Vis. Sci. 2004, 45, 3337-3348. [CrossRef]

37. Del Priore, L.V.; Geng, L.; Tezel, T.H.; Kaplan, H.J. Extracellular matrix ligands promote RPE attachment to inner Bruch's membrane. Curr. Eye Res. 2002, 25, 79-89. [CrossRef] [PubMed] 
38. Sugino, I.K.; Gullapalli, V.K.; Sun, Q.; Wang, J.; Nunes, C.F.; Cheewatrakoolpong, N.; Johnson, A.C.; Degner, B.C.; Hua, J.; Liu, T.; et al. Cell-deposited matrix improves retinal pigment epithelium survival on aged submacular human Bruch's membrane. Investig. Ophthalmol. Vis. Sci. 2011, 52, 1345-1358. [CrossRef]

39. Sugino, I.K.; Rapista, A.; Sun, Q.; Wang, J.; Nunes, C.F.; Cheewatrakoolpong, N.; Zarbin, M.A. A method to enhance cell survival on Bruch's membrane in eyes affected by age and age-related macular degeneration. Investig. Ophthalmol. Vis. Sci. 2011, 52, 9598-9609. [CrossRef] [PubMed]

40. Chaudhari, A.A.; Vig, K.; Baganizi, D.R.; Sahu, R.; Dixit, S.; Dennis, V.; Singh, S.R.; Pillai, S.R. Future Prospects for Scaffolding Methods and Biomaterials in Skin Tissue Engineering: A Review. Int. J. Mol. Sci. 2016, 17, 1974. [CrossRef] [PubMed]

41. Lam Van Ba, O.; Aharony, S.; Loutochin, O.; Corcos, J. Bladder tissue engineering: A literature review. Adv. Drug Deliv. Rev. 2015, 82-83, 31-37. [CrossRef]

42. Kessler, M.W.; Grande, D.A. Tissue engineering and cartilage. Organogenesis 2008, 4, 28-32. [CrossRef]

43. Wubneh, A.; Tsekoura, E.K.; Ayranci, C.; Uludag, H. Current state of fabrication technologies and materials for bone tissue engineering. Acta Biomater. 2018, 80,1-30. [CrossRef]

44. Mertens, J.P.; Sugg, K.B.; Lee, J.D.; Larkin, L.M. Engineering muscle constructs for the creation of functional engineered musculoskeletal tissue. Regen. Med. 2014, 9, 89-100. [CrossRef] [PubMed]

45. Chirila, T.; Barnard, Z.; Zainuddin; Harkin, D.G.; Schwab, I.R.; Hirst, L. Bombyx mori silk fibroin membranes as potential substrata for epithelial constructs used in the management of ocular surface disorders. Tissue Eng. Part A 2008, 14, 1203-1211. [CrossRef] [PubMed]

46. Siemann, U. Solvent cast technology-A versatile tool for thin film production. In Scattering Methods and Properties of Polymer Materials: Progress in Colloid and Polymer Science; Stribeck, N., Smarsly, B., Eds.; Springer: Berlin, Germany, 2005; Volume 130, pp. 1-14.

47. Giordano, G.G.; Thomson, R.C.; Ishaug, S.L.; Mikos, A.G.; Cumber, S.; Garcia, C.A.; Lahiri-Munir, D. Retinal pigment epithelium cells cultured on synthetic biodegradable polymers. J. Biomed. Res. 1997, 34, 87-93. [CrossRef]

48. Lai, J.; Li, Y. Evaluation of cross-linked gelatin membranes as delivery carriers for retinal sheets. Mater. Sci. Eng. C 2010, 30, 677-685. [CrossRef]

49. Lai, J. Influence of solvent composition on the performance of carbodiimide cross-linked gelatin carriers for retinal sheet delivery. J. Mater. Sci. Mater. Med. 2013, 24, 2201-2210. [CrossRef]

50. Shadforth, A.M.; Suzuki, S.; Alzonne, R.; Edwards, G.A.; Richardson, N.A.; Chirila, T.V.; Harkin, D.G. Incorporation of human recombinant tropoelastin into silk fibroin membranes with the view of repairing Bruch's membrane. J. Funct. Biomater. 2015, 6 , 946-962. [CrossRef]

51. Singh, A.K.; Srivastava, G.K.; Martin, L.; Alonso, M.; Pastor, J.C. Bioactive substrates for human retinal pigment epithelial cell growth from elastin-like recombinamers. J. Biomed. Mater. Res. A 2014, 102, 639-646. [CrossRef]

52. Galloway, C.A.; Dalvi, S.; Shadforth, A.M.A.; Suzuki, S.; Wilson, M.; Kuai, D.; Hashim, A.; MacDonald, L.A.; Gamm, D.M.; Harkin, D.G.; et al. Characterization of Human iPSC-RPE on a Prosthetic Bruch's Membrane Manufactured from Silk Fibroin. Investig. Ophthalmol. Vis. Sci. 2018, 59, 2792-2800. [CrossRef] [PubMed]

53. Tezcaner, A.; Bugra, K.; Hasirici, V. Retinal pigment epithelium cell culture on surface modified poly(hydroxybutyrate-cohydroxyvalerate) thin films. Biomaterials 2003, 24, 4573-4583. [CrossRef]

54. Prasad, A.; Sankar, M.R.; Katiyar, V. State of Art on Solvent Casting Particulate Leaching Method for Orthopedic Scaffolds Fabrication. Mater. Today 2017, 4, 898-907. [CrossRef]

55. Subia, B.; Kundu, J.; Kundu, S.C. Biomaterial scaffold fabrication techniques for potential tissue engineering applications. In Tissue Engineering; Eberli, D., Ed.; InTech: Rijeka, Croatia, 2010; pp. 141-157.

56. Shadforth, A.M.; George, K.A.; Kwan, A.S.; Chirila, T.V.; Harkin, D.G. The cultivation of human retinal pigment epithelium on Bombyx mori silk fibroin. Biomaterials 2012, 33, 4110-4117. [CrossRef]

57. McHugh, K.J.; Tao, S.L.; Saint-Geniez, M. Porous poly(epsilon-caprolactone) scaffolds for retinal pigment epithelium transplantation. Investig. Opthalmol. Vis. Sci. 2014, 55, 1754-1762. [CrossRef]

58. Calejo, M.T.; Ilmarinen, T.; Vuorimaa-Laukkanen, E.; Talvitie, E.; Hakola, H.M.; Skottman, H.; Kellomaki, M. Langmuir-Schaefer film deposition onto honeycomb porous films for retinal tissue engineering. Acta Biomater. 2017, 54, 138-149. [CrossRef]

59. Worthington, K.S.; Wiley, L.A.; Guymon, C.A.; Salem, A.K.; Tucker, B.A. Differentiation of Induced Pluripotent Stem Cells to Neural Retinal Precursor Cells on Porous Poly-Lactic-co-Glycolic Acid Scaffolds. J. Ocul. Pharmacol. Ther. 2016, 32, $310-316$. [CrossRef]

60. Janik, H.; Marzec, M. A review: Fabrication of porous polyurethane scaffolds. Mater. Sci. Eng. C Mater. Biol. Appl. 2015, 48, 586-591. [CrossRef] [PubMed]

61. El-Sherbiny, I.M.; Yacoub, M. Hydrogel scaffolds for tissue engineering: Progress and challenges. Glob. Cardiol. Sci. Pract. 2013, 3, 316-342. [CrossRef]

62. Maitra, J.; Shukala, V.K. Cross-linking in Hydrogels-A Review. Am. J. Polym. Sci 2014, 2, 25-31. [CrossRef]

63. Park, J.H.; Shin, E.Y.; Shin, M.E.; Choi, M.J.; Carlomagno, C.; Song, J.E.; Khang, G. Enhanced retinal pigment epithelium (RPE) regeneration using curcumin/alginate hydrogels: In vitro evaluation. Int. J. Biol. Macromol. 2018, 117, 546-552. [CrossRef] [PubMed] 
64. Kim, H.S.; Kim, D.; Jeong, Y.W.; Choi, M.J.; Lee, G.W.; Thangavelu, M.; Song, J.E.; Khang, G. Engineering retinal pigment epithelial cells regeneration for transplantation in regenerative medicine using PEG/Gellan gum hydrogels. Int. J. Biol. Macromol. 2019, 130, 220-228. [CrossRef] [PubMed]

65. Hunt, N.C.; Hallam, D.; Karimi, A.; Mellough, C.B.; Chen, J.; Steel, D.H.W.; Lako, M. 3D culture of human pluripotent stem cells in RGD-alginate hydrogel improves retinal tissue development. Acta Biomater. 2017, 49, 329-343. [CrossRef] [PubMed]

66. Gandhi, J.K.; Manzar, Z.; Bachman, L.A.; Andrews-Pfannkoch, C.; Knudsen, T.; Hill, M.; Schmidt, H.; Iezzi, R.; Pulido, J.S.; Marmorstein, A.D. Fibrin hydrogels as a xenofree and rapidly degradable support for transplantation of retinal pigment epithelium monolayers. Acta Biomater. 2018, 67, 134-146. [CrossRef] [PubMed]

67. Lu, J.T.; Lee, C.J.; Bent, S.F.; Fishman, H.A.; Sabelman, E.E. Thin collagen film scaffolds for retinal epithelial cell culture. Biomaterials 2007, 28, 1486-1494. [CrossRef] [PubMed]

68. Hertz, J.; Robinson, R.; Valenzuela, D.A.; Lavik, E.B.; Goldberg, J.L. A tunable synthetic hydrogel system for culture of retinal ganglion cells and amacrine cells. Acta Biomater. 2013, 9, 7622-7629. [CrossRef] [PubMed]

69. Roozafzoon, R.; Lashay, A.; Vasei, M.; Ai, J.; Khoshzaban, A.; Keshel, S.H.; Barabadi, Z.; Bahrami, H. Dental pulp stem cells differentiation into retinal ganglion-like cells in a three dimensional network. Biochem. Biophys. Res. Commun. 2015, 457, 154-160. [CrossRef]

70. Soleimannejad, M.; Ebrahimi-Barough, S.; Soleimani, M.; Nadri, S.; Tavangar, S.M.; Roohipoor, R.; Yazdankhah, M.; Bayat, N.; Riazi-Esfahani, M.; Ai, J. Fibrin gel as a scaffold for photoreceptor cells differentiation from conjunctiva mesenchymal stem cells in retina tissue engineering. Artif. Cells Nanomed. Biotechnol. 2018, 46, 805-814. [CrossRef]

71. Conoscenti, G.; Carrubba, V.L.; Brucato, V. A versatile technique to produce porous polymeric scaffolds: The Thermally Induced Phase Separation (TIPS) method. Arch. Chem. Res. 2017, 1. [CrossRef]

72. Lu, T.; Li, Y.; Chen, T. Techniques for fabrication and construction of three-dimensional scaffolds for tissue engineering. Int. J. Nanomed. 2013, 8, 337-350. [CrossRef]

73. Akbarzadeh, R.; Yousefi, A. Effects of processing parameter in thermally induced phase separation technique on porous architecture of scaffolds for bone tissue engineering. J. Biomed. Mater. Res. B Appl. Biomater. 2014, 102, 1304-1315. [CrossRef]

74. Turnbull, G.; Clarke, J.; Picard, F.; Riches, P.; Jia, L.; Han, F.; Li, B.; Shu, W. 3D bioactive composite scaffolds for bone tissue engineering. Bioact. Mater. 2018, 3, 278-314. [CrossRef]

75. Martinez-Perez, C.A.; Olivas-Armendariz, I.; Castro-Carmona, J.S.; Garcia-Casillas, P.E. Scaffolds for tissue engineering via thermally induced phase separation. In Advances in Regenerative Medicine; Wislet-Gendebien, S., Ed.; InTech Open: London, UK, 2011; pp. 275-294.

76. Thomson, H.A.J.; Treharne, A.J.; Walker, P.; Grossel, M.C.; Lotery, A.J. Optimisation of polymer scaffolds for retinal pigment epithelium (RPE) cell transplantation. Br. J. Ophthalmol. 2011, 95, 563-568. [CrossRef]

77. Lavik, E.B.; Klassen, H.; Warfvinge, K.; Langer, R.; Young, M.J. Fabrication of degradable polymer scaffolds to direct the integration and differentiation of retinal progenitors. Biomaterials 2005, 26, 3187-3196. [CrossRef] [PubMed]

78. Hotaling, N.A.; Khristov, V.; Wan, Q.; Sharma, R.; Jha, B.S.; Lotfi, M.; Maminishkis, A.; Simon, C.G., Jr.; Bharti, K. Nanofiber Scaffold-Based Tissue-Engineered Retinal Pigment Epithelium to Treat Degenerative Eye Diseases. J. Ocul. Pharmacol. Ther. 2016, 32, 272-285. [CrossRef] [PubMed]

79. Rahmati, M.; Mills, D.K.; Urbanska, A.M.; Reza Saeb, M.; Venugopal, J.R.; Ramakrishna, S.; Mozafari, M. Electrospinning for Tissue Engineering Applications. Prog. Mater. Sci. 2020, 100721. [CrossRef]

80. Bhardwaj, N.; Kundu, S.C. Electrospinning: A fascinating fiber fabrication technique. Biotechnol. Adv. 2010, $28,325-347$. [CrossRef]

81. Beachley, V.; Wen, X. Effect of electrospinning parameters on the nanofiber diameter and length. Mater. Sci. Eng. C Mater. Biol. Appl. 2009, 29, 663-668. [CrossRef] [PubMed]

82. Hasan, A.; Memic, A.; Annabi, N.; Hossain, M.; Paul, A.; Dokmeci, M.R.; Dehghani, F.; Khademhosseini, A. Electrospun scaffolds for tissue engineering of vascular grafts. Acta Biomater. 2014, 10, 11-25. [CrossRef]

83. Kitsara, M.; Agbulut, O.; Kontziampasis, D.; Chen, Y.; Menasché, P. Fibers for heart: A critical review on electrospinning for cardiac tissue engineering. Acta Biomater. 2017, 48, 20-40. [CrossRef]

84. Xie, J.; MacEwan, M.R.; Schwartz, A.G.; Xia, Y. Electrospun nanofibers for neural tissue engineering. Nanoscale 2010, 2, 35-44. [CrossRef]

85. Warnke, P.H.; Alamein, M.; Skabo, S.; Stephens, S.; Bourke, R.; Heiner, P.; Liu, Q. Primordium of an artificial Bruch's membrane made of nanofibers for engineering of retinal pigment epithelium cell monolayers. Acta Biomater. 2013, 9, 9414-9422. [CrossRef] [PubMed]

86. Xiang, P.; Wu, K.C.; Zhu, Y.; Xiang, L.; Li, C.; Chen, D.L.; Chen, F.; Xu, G.; Wang, A.; Li, M.; et al. A novel Bruch's membrane mimetic electrospun substrate scaffold for human retinal pigment epithelium cells. Biomaterials 2014, 35, 9777-9788. [CrossRef] [PubMed]

87. Zhang, D.; Ni, N.; Chen, J.; Yao, Q.; Shen, B.; Zhang, Y.; Zhu, M.; Wang, Z.; Ruan, J.; Wang, J.; et al. Electrospun SF/PLCL nanofibrous membrane: A potential scaffold for retinal progenitor cell proliferation and differentiation. Sci. Rep. 2015, 5, 14326. [CrossRef] 
88. Popelka, Š.; Studenovská, H.; Abelová, L.; Ardan, T.; Studený, P.; Straňák, Z.; Klíma, J.; Dvořánková, B.; Kotek, J.; Hodan, J.; et al. A frame-supported ultrathin electrospun polymer membrane for transplantation of retinal pigment epithelial cells. Biomed. Mater. 2015, 10. [CrossRef] [PubMed]

89. Surrao, D.C.; Greferath, U.; Chau, Y.Q.; Skabo, S.J.; Huynh, M.; Shelat, K.J.; Limnios, I.J.; Fletcher, E.L.; Liu, Q. Design, development and characterization of synthetic Bruch's membranes. Acta Biomater. 2017, 64, 357-376. [CrossRef] [PubMed]

90. Thieltges, F.; Stanzel, B.V.; Liu, Z.; Holz, F.G. A nanofibrillar surface promotes superior growth characteristics in cultured human retinal pigment epithelium. Ophthalmic Res. 2011, 46, 133-140. [CrossRef]

91. Noorani, B.; Tabandeh, F.; Yazdian, F.; Soheili, Z.; Shakibaie, M.; Rahmani, S. Thin natural gelatin/chitosan nanofibrous scaffolds for retinal pigment epithelium cells. Int. J. Polym. Mater. Polym. Biomater. 2017, 67, 754-763. [CrossRef]

92. Liu, Z.; Yu, N.; Holz, F.G.; Yang, F.; Stanzel, B.V. Enhancement of retinal pigment epithelial culture characteristics and subretinal space tolerance of scaffolds with $200 \mathrm{~nm}$ fiber topography. Biomaterials 2014, 35, 2837-2850. [CrossRef]

93. Shahmoradi, S.; Yazdian, F.; Tabandeh, F.; Soheili, Z.S.; Hatamian Zarami, A.S.; Navaei-Nigjeh, M. Controlled surface morphology and hydrophilicity of polycaprolactone toward human retinal pigment epithelium cells. Mater. Sci. Eng. C Mater. Biol. Appl. 2017, 1, 300-309. [CrossRef]

94. Sorkio, A.; Porter, P.J.; Juuti-Uusitalo, K.; Meenan, B.J.; Skottman, H.; Burke, G.A. Surface Modified Biodegradable Electrospun Membranes as a Carrier for Human Embryonic Stem Cell-Derived Retinal Pigment Epithelial Cells. Tissue Eng. Part A 2015, 21, 2301-2314. [CrossRef]

95. Sharma, R.; Khristov, V.; Rising, A.; Jha, B.S.; Dejene, R.; Hotaling, N.; Li, Y.; Stoddard, J.; Stankewicz, C.; Wan, Q.; et al. Clinical-grade stem cell-derived retinal pigment epithelium patch rescues retinal degeneration in rodents and pigs. Sci. Transl. Med. 2019, 16, 475. [CrossRef]

96. Tian, Y.; Zonca, M.R.; Imbrogno, J.; Unser, A.M.; Sfakis, L.; Temple, S.; Belfort, G.; Xie, Y. Polarized, Cobblestone, Human Retinal Pigment Epithelial Cell Maturation on a Synthetic PEG Matrix. ACS Biomater. Sci. Eng. 2017, 3, 890-902. [CrossRef] [PubMed]

97. Rahmani, S.; Tabandeh, F.; Faghihi, S.; Amoabediny, G.; Shakibaie, M. Fabrication of poly( $\varepsilon$-caprolactone)/gelatin nanofibrous scaffolds for retinal tissue engineering. Int. J. Polym. Mater. Polym. Biomater. 2018, 67, 27-35. [CrossRef]

98. Da Silva, G.R.; Lima, T.H.; Oréfice, R.L.; Fernandes-Cunha, G.M.; Silva-Cunha, A.; Zhao, M.; Behar-Cohen, F. In vitro and in vivo ocular biocompatibility of electrospun poly( $\varepsilon$-caprolactone) nanofibers. Eur. J. Pharm. Sci. 2015, 20, 9-19. [CrossRef] [PubMed]

99. Chen, H.; Fan, X.; Xia, J.; Chen, P.; Zhou, X.; Huang, J.; Yu, J.; Gu, P. Electrospun chitosan-graft-poly ( $\varepsilon$-caprolactone)/poly ( $\varepsilon$-caprolactone) nanofibrous scaffolds for retinal tissue engineering. Int. J. Nanomed. 2011, 6, 453-461. [CrossRef]

100. Belgio, B.; Boschetti, F.; Mantero, S. Towards an In Vitro Retinal Model to Study and Develop New Therapies for Age-Related Macular Degeneration. Bioengineering 2021, 8, 18. [CrossRef]

101. Kador, K.E.; Montero, R.B.; Venugopalan, P.; Hertz, J.; Zindell, A.N.; Valenzuela, D.A.; Uddin, M.S.; Lavik, E.B.; Muller, K.J.; Andreopoulos, F.M.; et al. Tissue engineering the retinal ganglion cell nerve fiber layer. Biomaterials 2013, 34, 4242-4250. [CrossRef]

102. Kador, K.E.; Alsehli, H.S.; Zindell, A.N.; Lau, L.W.; Andreopoulos, F.M.; Watson, B.D.; Goldberg, J.L. Retinal ganglion cell polarization using immobilized guidance cues on a tissue-engineered scaffold. Acta Biomater. 2014, 10, 4939-4946. [CrossRef]

103. Li, K.; Zhong, X.; Yang, S.; Luo, Z.; Li, K.; Liu, Y.; Cai, S.; Gu, H.; Lu, S.; Zhang, H.; et al. HiPSC-derived retinal ganglion cells grow dendritic arbors and functional axons on a tissue-engineered scaffold. Acta Biomater. 2017, 54, 117-127. [CrossRef]

104. Nadri, S.; Kazemi, B.; Eslaminejad, M.B.; Yazdani, S.; Soleimani, M. High yield of cells committed to the photoreceptor-like cells from conjunctiva mesenchymal stem cells on nanofibrous scaffolds. Mol. Biol. Rep. 2013, 40, 3883-3890. [CrossRef]

105. Dalton, P.D. Melt electrowriting with additive manufacturing principles. Curr. Opin. Biomed. Eng. 2017, 2, 49-57. [CrossRef]

106. Saidy, N.T.; Shabab, T.; Bas, O.; Rojas-Gonzalez, D.M.; Menne, M.; Henry, T.; Hutmacher, D.W.; Mela, P.; De-Juan-Pardo, E.M. Melt Electrowriting of Complex 3D Anatomically Relevant Scaffolds. Front. Bioeng. Biotechnol. 2020. [CrossRef] [PubMed]

107. Brennan, C.M.; Eichholz, K.F.; Hoey, D.A. The effect of pore size within fibrous scaffolds fabricated using melt electrowriting on human bone marrow stem cell osteogenesis. Biomed. Mater. 2019, 14. [CrossRef] [PubMed]

108. Hewitt, E.; Mros, S.; McConnell, M.; Cabral, J.D.; Ali, A. Melt-electrowriting with novel milk protein/PCL biomaterials for skin regeneration. Biomed. Mater. 2019, 14, 055013. [CrossRef] [PubMed]

109. Tran, K.T.M.; Nguyen, T.D. Lithography-based methods to manufacture biomaterials at small scales. J. Sci. Adv. Mater. Devices 2017, 2, 1-14. [CrossRef]

110. Neeley, W.L.; Redenti, S.; Klassen, H.; Tao, S.; Desai, T.; Young, M.J.; Langer, R. A microfabricated scaffold for retinal progenitor cell grafting. Biomaterials 2008, 29, 418-426. [CrossRef] [PubMed]

111. Steedman, M.R.; Tao, S.L.; Klassen, H.; Desai, T.A. Enhanced differentiation of retinal progenitor cells using microfabricated topographical cues. Biomed. Microdevices 2010, 12, 363-369. [CrossRef]

112. Redenti, S.; Neeley, W.L.; Rompani, S.; Saigal, S.; Yang, J.; Klassen, H.; Langer, R.; Young, M.J. Engineering retinal progenitor cell and scrollable poly(glycerol-sebacate) composites for expansion and subretinal transplantation. Biomaterials 2009, 30, 3405-3414. [CrossRef]

113. Lu, B.; Zhu, D.; Hinton, D.; Humayun, M.S.; Tai, Y.C. Mesh-supported submicron parylene-C membranes for culturing retinal pigment epithelial cells. Biomed. Microdevices 2012, 14, 659-667. [CrossRef]

114. Kashani, A.H.; Lebkowski, J.S.; Rahhal, F.M.; Avery, R.L.; Salehi-Had, H.; Dang, W.; Lin, C.M.; Mitra, D.; Zhu, D.; Thomas, B.B.; et al. A bioengineered retinal pigment epithelial monolayer for advanced, dry age-related macular degeneration. Sci. Transl. Med. 2018, 4, 435. [CrossRef] 
115. Gleadall, A.; Visscher, D.; Yang, J.; Thomas, D.; Segal, J. Review of additive manufactured tissue engineering scaffolds: Relationship between geometry and performance. Burn. Trauma 2018, 6, 19. [CrossRef] [PubMed]

116. Aimar, A.; Palermo, A.; Innocenti, B. The Role of 3D Printing in Medical Applications: A State of the Art. J. Healthc. Eng. 2019, 10. [CrossRef] [PubMed]

117. Moroni, L.; Burdick, J.A.; Highley, C.; Lee, S.J.; Morimoto, Y.; Takeuchi, S.; Yoo, J.J. Biofabrication strategies for 3D in vitro models and regenerative medicine. Nat. Rev. Mater. 2018, 3, 21-37. [CrossRef] [PubMed]

118. Mantero, S.; Sadr, N.; Riboldi, S.A.; Lorenzoni, S.; Montevecchi, F.M. A new electro-mechanical bioreactor for soft tissue engineering. J. Appl. Biomater. Biomech. 2007, 5, 107-116. [PubMed]

119. He, P.; Zhao, J.; Zhang, J.; Li, B.; Gou, Z.; Gou, M.; Li, X. Bioprinting of skin constructs for wound healing. Burn. Trauma 2018, 6. [CrossRef]

120. Vukievic, M.; Mosadegh, B.; Little, J.K.; Little, S.H. Cardiac 3D printing and its future directions. JACC Cardiovasc. Imaging 2017, 10, 171-184. [CrossRef]

121. Mannoor, M.S.; Jiang, Z.; James, T.; Kong, Y.L.; Malatesta, K.A.; Soboyejo, W.O.; Verma, N.; Gracias, D.H.; McAlpine, M.C. 3D printed bionic ears. Nano Lett. 2013, 13, 2634-2639. [CrossRef] [PubMed]

122. Li, J.; Chen, M.; Fan, X.; Zhou, H. Recent advances in bioprinting techniques: Approaches, applications and future prospects. J. Transl. Med. 2016, 14. [CrossRef]

123. Lorber, B.; Hsiao, W.K.; Hutchings, I.M.; Martin, K.R. Adult rat retinal ganglion cells and glia can be printed by piezoelectric inkjet printing. Biofabrication 2014, 6. [CrossRef]

124. Masaeli, E.; Forster, V.; Picaud, S.; Karamali, F.; Nasr-Esfahani, M.H.; Marquette, C. Tissue engineering of retina through high resolution 3-dimensional inkjet bioprinting. Biofabrication 2020, 12. [CrossRef]

125. Schwab, A.; Levato, R.; D’Este, M.; Piluso, S.; Eglin, D.; Malda, J. Printability and Sahe Fidelity of Bioiks in 3D Bioprinting. Chem. Rev. 2020, 120, 11028-11055. [CrossRef]

126. Shi, P.; Tan, Y.S.E.; Yeong, W.Y.; Li, H.Y.; Laude, A. A bilayer photoreceptor-retinal tissue model with gradient cell density design: A study of microvalve-based bioprinting. J. Tissue Eng. Regen. Med. 2018, 12, 1297-1306. [CrossRef] [PubMed]

127. Tan, E.Y.S.; Agarwala, S.; Yap, Y.L.; Tan, C.S.H.; Laude, A.; Yeong, W.Y. Novel method for the fabrication of ultrathin, free-standing and porous polymer membranes for retinal tissue engineering. J. Mater. Chem. B 2017, 5, 5616-5622. [CrossRef]

128. Zorlutuna, P.; Builles, N.; Damour, O.; Elsheikh, A.; Hasirci, V. Influence of keratocytes and retinal pigment epithelial cells on the mechanical properties of polyester-based tissue engineering micropatterned films. Biomaterials 2007, 28, 3489-3496. [CrossRef]

129. Shi, P.; Edgar, T.Y.S.; Yeong, W.Y.; Laude, A. Hybrid three-dimensional (3D) bioprinting of retina equivalent for ocular research. Int. J. Bioprint. 2017, 3. [CrossRef]

130. Kador, K.E.; Grogan, S.P.; Dorthé, E.W.; Venugopalan, P.; Malek, M.F.; Goldberg, J.L.; D’lima, D.D. Control of Retinal Ganglion Cell Positioning and Neurite Growth: Combining 3D Printing with Radial Electrospun Scaffolds. Tissue Eng. Part A 2016, 22, 286-294. [CrossRef] [PubMed] 